Please do not remove this page

RMIT

UNIVERSITY

\title{
The ties that bind: Family barriers for adult women seeking to report childhood sexual assault in Australia
}

Taylor, S. Caroline; Norma, Caroline

https://researchrepository.rmit.edu.au/esploro/outputs/9921859204501341/filesAndLinks?institution=61RMIT_INST\&index=null

Taylor, S. C., \& Norma, C. (2012). The ties that bind: Family barriers for adult women seeking to report childhood sexual assault in Australia. Women's Studies International Forum, 37, 114-124.

https://doi.org/10.1016/j.wsif.2012.11.004

Document Version: Accepted Manuscript

Published Version: https://doi.org/10.1016/j.wsif.2012.11.004

Repository homepage: https://researchrepository.rmit.edu.au

(c) 2012 Elsevier Ltd. All rights reserved.

Downloaded On 2023/04/26 19:27:47 +1000 
Thank you for downloading this document from the RMIT Research Repository.

The RMIT Research Repository is an open access database showcasing the research outputs of RMIT University researchers.

RMIT Research Repository: http://researchbank.rmit.edu.au/

\section{Citation:}

Taylor, S and Norma, C 2012, 'The ties that bind: Family barriers for adult women seeking to report childhood sexual assault in Australia', Women's Studies International Forum, vol. 37, pp. 114-124.

See this record in the RMIT Research Repository at:

https://researchbank.rmit.edu.au/view/rmit:26602

Version: Accepted Manuscript

Copyright Statement: ㄷ 2012 Elsevier Ltd. All rights reserved.

Link to Published Version:

http://dx.doi.org/10.1016/j.wsif.2012.11.004 


\title{
The ties that bind: Family barriers for adult women seeking to report childhood sexual assault in Australia
}

\author{
S. Caroline Taylor ${ }^{\mathrm{a}, *}$, Caroline Norma ${ }^{\mathrm{b}}$ \\ ${ }^{a}$ Edith Cowan University, 270 Joondalup Drive, Joondalup, WA 6027, Australia \\ b RMIT University, Melbourne, Australia
}

\section{A R T I C L E I N F O}

Available online $\mathrm{xxxx}$

\begin{abstract}
S Y N O P S I S
In this article, we observe that barriers to the disclosure and reporting of sexual assault reside within families. We draw on qualitative survey data, as well as interviews with adult victims of childhood sexual assault, to show how women are impeded by family members when attempting to disclose or report sexual assault. Taylor and Putt (2007) identified three 'family constraints on [sexual violence] reporting' for women from culturally and linguistically diverse (CALD) backgrounds in Australia. These were: 1) Family denial that sexual violence exists, 2) Reluctance to report a partner perpetrator, and 3) Fear of being ostracised for bringing shame upon the family (p. 4). We examine whether similar barriers to reporting exist for adult female survivors of childhood sexual assault who are from non-CALD backgrounds. On the basis of our findings, we urge greater police and public recognition of, and sensitivity to barriers extant within non-CALD families that contribute to the under-reporting of sexual assault by women in Australia.
\end{abstract}

(c) 2012 Published by Elsevier Ltd.

\section{Introduction}

Many barriers to the disclosure and reporting of sexual assault can be found within families. Feminist criminologist Denise Lievore writes that, "if the [sex] offence occurs within the family[,]...[f]amily members may not want to hear about the abuse; may be unwilling to become involved; may not believe that their male relative was violent..." (Lievore, 2003, p. 80). However, only a handful of studies have explored in depth this problem of family members resisting the disclosing and reporting efforts of survivors, and this scholarship is mostly concerned with the reactions of partners or with "social networks" in general (Australian Institute of Family Studies, 2007; Davis \& Brickman, 1996; Davis, Taylor, \& Bench, 1995; Ullman \& Najdowski, 2011). The most substantial comment on the topic is found within the (mostly) Australian literature that

\footnotetext{
is The authors would like to sincerely thank the three anonymous reviewers for the great deal of time and effort they gave to suggesting improvements in the article.

* Corresponding author.
}

discusses difficulties faced by Culturally and Linguistically Diverse (CALD) and Indigenous women who seek to report sexual assault in the absence of family or community support (Aly \& Gaba, 2007; Department of Families, Community Services and Indigenous Affairs, 2007; Fairfield Multicultural Family Planning, 1996; Fairfield Multicultural Family Planning, 1996; Neame \& Heenan, 2004; Rubin, 2010). Taylor and Putt (2007), for example, identified three family constraints on reporting for female victims of sexual violence from CALD backgrounds in Australia. These were: 1) Family denial that sexual violence exists, 2) Reluctance to report a partner perpetrator, and 3) Fear of being ostracised for bringing shame upon the family (p. 4). According to a Women's Health Services Australia publication, CALD victims of sexual assault experience particular difficulty with family members when they seek to report because "issues to do with rape and sexual assault are still shrouded in secrecy and shame" in their communities (Fairfield Multicultural Family Planning, 1996, p. 3). A report from an Australian federal government agency in 2004 explains that "[c]ultural issues... impact on the reporting of sexual assaults, as it is considered "shame", not necessarily to be sexually assaulted, but to report 
sexual assaults" (Neame \& Heenan, 2004, p. 14, their italics). In this article, we examine whether similar family-based barriers to the disclosure and reporting of sexual assault exist for victims who do not belong to CALD communities in Australia.

We pursue this discussion in order to encourage greater sensitivity and responsiveness on the part of police and the public to the possibility that women in Australia are impeded by family members when attempting to disclose or report sexual assault. We focus on non-CALD families, but we recognise that issues of family shame and honour comprise a particularly serious and pernicious barrier to reporting for women from some CALD groups (Fairfield Multicultural Family Planning, 1996; Women's Legal Services NSW, 2007). It is not our intention to overlook this experience. On the contrary, research on the experiences of CALD women alerted us to the possibility of similar barriers-even if different in degree-arising in the experience of non-CALD survivors of sexual assault.

The question that guides our research was posed by Lievore (2003). She asked "whether families and friends prevent access or provide a pathway to further help seeking from legal and professional sources of support or vice versa" (p. 18). Research on the experience of CALD and Indigenous women answers this question to some degree, but examining a broader population of women is useful for confirming the findings of this scholarship. On this basis, as we discuss below, we test whether Taylor \& Putt's, 2007 aforementioned three family constraints on reporting (i.e., family denial that sexual abuse occurred, reluctance to report a partner ${ }^{1}$ perpetrator, and fear of being ostracised for bringing shame upon the family) are also part of the experience of non-CALD female survivors of sexual assault in Australia. We extend these family constraints a little further to include evidence of harm minimisation by family members, intimidation and threats by perpetrators and sometimes other family members, and families expelling victims from the family unit for disclosing and/or reporting to police.

To some extent, women's services in Australia already recognise the need for intervention to encourage nonperpetrating family members to better support survivors. In a campaign run by the Fairfield Immigrant \& Refugee Women's Network NSW (Australia) in the mid 1990s it was stressed that "non-offending members of the family like sisters and mothers need to be supportive of the victim and take a firm stand against the perpetrator" (Fairfield Multicultural Family Planning, 1996; pp. 29-30). In this campaign, increased solidarity among female family members was seen as a way to combat family-based obstacles to victims speaking out. It did not, however, directly call on victims to make police reports in the style of the 2008 London Metropolitan Police campaign 'Don't be afraid to report rape and sexual assault' (http://content.met.police.uk/Article/Dontbe-afraid-to-report-rape-and-sexual-assault-Campaign-results/ 1400002039898/sapphirecampaign08). While informal disclosure to friends and family members may positively influence the likelihood of police reporting (Lievore, 2005, p. 38), in the absence of clear public exhortations to report the crime, victims may remain vulnerable to intimidation or dissuasion by family members (including perpetrators) who have an interest in keeping matters "private". For this reason, in this article we explore family-related barriers that prevent women coming forward as victims of sexual assault in order that public agencies like the police may consider incorporating measures against family interference in future campaigns to increase sexual assault reporting.

\section{Theoretical approach and previous research}

Our focus in this article on the role that family members play in the delayed or non-reporting of sexual assault is theoretically informed by the work of Catherine Itzin (2001). Itzin describes in vivid terms the situation of children in families who are sexually abused by male household members. She describes these children as suffering "pain, humiliation and torment", and as incurring "permanent emotional damage" as a result of the abuse. Itzin notes that these children make up a population that is "captive... and vulnerable". Significantly, she writes that this 'capture' necessarily "involves deceiving and disarming adults, and in particular the children's mothers" (p. 45). Such deception is carried out by perpetrators who "may be good at their jobs and respected by their colleagues", and are also "adept at avoiding detection and criminal charges". Most importantly, these perpetrators "are inadvertently assisted by the assumptions and values of our social institutions" (p. 45). While, in this article, we draw on interview and survey data from adult survivors of childhood sexual assault (and not children), Itzin's (2001) insights are nonetheless useful for their articulation of the way in which perpetrators can be assisted in their crimes by the 'assumptions and values' of the social institutions around them.

Understanding intrafamilial sexual assault crime in this way allows us to avoid the "incest family" or "dysfunctional family" approach that is popular in the psychology and social science literature discussing abuse in the family. Feminist scholars have been vocal in condemning the development and mobilisation of a discourse that located mothers as the causative agent of men's sexual assault and rape of their children in the family unit. $^{2}$ Sarah Ruddick's (1997) alternative argument is that "the family"-when it is constructed out of the idea of "fatherhood"-is detrimental to the wellbeing of women and children to the extent that fatherhood is accompanied by "a right...to intrude, humiliate, exploit, and assault” (p. 213). Historically men as fathers and husbands have been legally and socially sanctioned and vested with significant power and status both within the family and society at large. Taylor's work exposed and made explicit the status accorded to "fathers" accused of committing sexual crimes against their child/ren (Taylor, 2001, 2004). Similar can be said for domestic violence. We concur that, when fatherhood is the organising principle of families and is afforded a degree of power and credibility not afforded women and children, this imbalance of power and rights creates significant barriers for women and children to speak and to disclose acts of violence perpetrated upon them. Moreover, it can create a family climate where members feel unable to protect others being victimised by the father. Accordingly, family members may emotionally withdraw from victims by declaring their support for perpetrators, in spite of the offences committed. Russell (1986, p. 370) has noted that one cause of this misplaced family loyalty is the fact that "[n]ot only does the person with the good reputation have a stake in that reputation, but often others do too. When reality conflicts with the reputation, some people prefer to uphold the reputation". This insight is particularly relevant to cases in which mothers protect perpetrator fathers against daughters. The ability of mothers to protect daughters is diminished in 
families that are organised around the principle of "fatherhood" because, in Ruddick's understanding, women lose "cognitive or moral authority". Similarly, daughters experience "confusion, resentment, and contempt when confronted with the submissiveness of a mother who in their eyes is powerful and, in the absence of the father, often trustworthy" (Ruddick, 1997, p. 213) Taylor has commented on the notion of the "good father" and "good citizen" that is often woven into the fabric of the family and community life of perpetrators, that often leads family members and the wider community to question the credibility of a victim's disclosure over the cultivated facade of the perpetrator (Taylor, 2004, p. 274).

A publication by Donna Rafanello (2004) is the only work we found containing substantial qualitative data from survivors on problems experienced with family members when disclosing or reporting sexual assault. Taylor (2004) identified similar problems but her data was confined to victim police statements and impact statements which detailed barriers and threats erected by family members and the dreadful reality of being expunged from the family unit for disclosing and/or reporting the father for the sexual abuse committed upon them. Rafanello interviewed sixty lesbians at length about various aspects of their lives as survivors, and a number of her interview questions elicited qualitative data about respondents' experience of disclosing to family members. Her respondents came from 28 different states of the US, as well as from New Zealand and Canada. They ranged in age from 18 to 66 years. Unfortunately, Rafenello does not disaggregate her data according to the linguistic or cultural background of respondents, so it is not possible to tell how many respondents came from 'Hispanic, African-American, Latina, White, Asian, Native American and Polynesian' backgrounds, as she describes her research sample. Regardless of background, though, Rafenello describes her respondents as generally citing negative reactions to their disclosures of intrafamilial sexual assault to non-perpetrating family members. While Rafenello does not thematically categorise her data according to the nature of obstacles faced by survivors in disclosing or reporting, as we attempt in this article, the following comment from one of her respondents is typical:

In my family I'm the big liar. When I wrote my mom a letter about the abuse, she had a fit. When she asked my dad he denied it. So she said it must not have happened. What else is he going to say? 'Of course I did'? She said I was doing this to hurt her. She said it never happened (p. 97).

While there exists only limited research on the issue of family barriers to sexual assault reporting, police are nonetheless aware that family-related factors contribute in some way to low reporting rates for crimes of violence against women. A report from Victoria Police (2009), for example, notes that:

it is very difficult for victims to take action against their own partners and family members. Fear of ostracism, reprisals against themselves and their children, and disbelief from family, friends and police are some of the reasons why [these] women find it so hard to report (p. 8).

Melanie Heenan and Suellen Murray in 2006 further noted that members of the Criminal Investigation Unit (CIU) and the Sexual Offences and Child Abuse Unit (SOCAU) of Victoria
Police believe that victims withdraw complaints of sexual assault because of "pressure from family" in intra-familial (i.e., incest) cases (Heenan \& Murray, 2006, p. 12).

This recognition by police of family-related factors as influencing reporting is somewhat ahead of academic literature. Most scholarly discussion of the under-reporting of sexual offences to police focuses on decision-making by individual victims, which is seen to follow a "cost-benefit calculation", the results of which "determine whether contacting the police [would be] worth the effort" (Goudriaan, Lynch, \& Nieuwbeerta, 2004, p. 934). While institutional barriers like the legal system feature in the academic discussion, family (and community) influences are left largely unconsidered. A typical example is Lievore's, 2003 research, which divides "barriers to reporting" into "personal barriers" and, "barriers related to the criminal justice system" (p. 27). These two categories frame much of the existing scholarly discussion of sexual assault non-reporting (see Home Office Research, Development and Statistics Directorate, 2005; Jordan, 2004).

This focus on individual victims is being gradually broadened to include social factors that impede victims in approaching police, and a broader, political view of the causes of sexual assault underreporting is starting to emerge in the feminist criminological literature. This scholarship looks outside the perceptions of victims-and outside institutional impediments to reporting imposed by the courts-toward obstacles posed by local communities. Pamela Rubin's (2010) work, for example, draws on interviews conducted with 125 female survivors of domestic violence in the Canadian state of Nova Scotia in 2000. Rubin found there was a "systematic failure to provide safety for abused women in [Nova Scotia], and a lack of community and awareness and understanding" (p. 80). She writes that her interviewees testified that there was "community hostility to abused women" and, therefore, "[f]or many women, community shrank and changed radically after...surviving abuse" (p. 80). They described feeling "shock and despair when trusted community members directed... [victim-blaming hostility] at them and supported the abuser or assailant" (p. 80). In Australia, Andrea Neame and Melanie Heenan have similarly noted community-based barriers to sexual assault reporting for women living in non-metropolitan areas. They found, similar to Rubin, that

[w]omen's responses to sexual violence, the range of options that are available to them, and their own capacity to take action after an assault will all be affected by the sociocultural dynamics of the place in which they live (2004, p. 6).

Research by Taylor on the difficulties often posed by smaller communities for victims of intrafamilial sexual abuse observed:

Relationships among community members may create situations in which child abuse, domestic violence and sexual violence is difficult to report and/or follow up. It is possible that community members may close ranks to inhibit proper investigation, stigmatise the victim or offender or treat those who report such offences...as a whistleblower (Taylor, 2003-2004, p. 13).

This view of sexual assault reporting, in which structural constraints extant in the community are understood to play a part in women's inability to achieve recourse for crime looks 
beyond individual factors. It is an approach to the problem of sexual assault under-reporting that emphasises the responsibility of wider society to create an environment that facilitates reporting, regardless of personal barriers that individuals may face.

\section{Methods and data}

In 2010, we advertised an online survey in newspapers and via radio advertisements in the state of Victoria (Australia), and via posters in police stations and other public domains. Our advertising solicited participation by adult sexual assault victims currently residing in the state of Victoria who were willing to discuss their decision-making in regards to (non-)reporting of sexual assault crime to police. The online survey questions were piloted among a group of fourteen female survivors and two male survivors, and modified according to their feedback. The survey questions elicited quantitative as well as qualitative data, but we draw only on qualitative responses in this article. The survey was completed by 336 respondents, of which $88 \%$ were female and $12 \%$ male. Just under $60 \%$ of respondents entered a metropolitan Victorian postcode. Of the total sample, $14 \%$ of respondents were from non-English speaking backgrounds, and 2.4\% identified as either Aboriginal or Torres Strait Islander. Overall, 130 had reported to police, and the majority of respondents who had reported to police had done so in the previous four years (2006 to 2010). Significantly, 43\% of respondents reported sexual assault beginning in childhood.

A total of 64 survey respondents elected to participate in a subsequent semi-structured, in-depth individual or focus group interview about their views, feelings, and experiences of (non-) reporting to Victoria Police (47 respondents chose individual interviews). Of these, 36 interviewees had contacted police for the purpose of reporting. Interviews were carried out over three months in mid-2010, and sex-segregated focus groups were held with no more than four participants. The individual interviews were held at community centres or venues close to where respondents were working or living. Payment was not offered but a "thank you" gift was given at the end of each interview. Researchers ensured that counsellors were on hand for focus group interviews, and individual interviewees were given information on where help was available if needed. One interview was conducted in the presence of the participant's psychologist, and one respondent submitted written testimony of her experience of police reporting (she did not feel comfortable enough to meet with researchers). Most individual interviews lasted one hour, but one extended to three hours, and focus groups generally exceeded two hours. Twelve per cent of interviewees came from CALD backgrounds, but in this article we draw only on data from female survivors of childhood sexual assault who self-identified as Caucasian.

Analysis of the qualitative survey and interview data involved a close, line-by-line reading by three researchers in order to achieve a degree of triangulation at the researcher level (see Minichiello, Sullivan, Greenwood, \& Axford, 2003; Perlesz \& Lindsay, 2003). This reading resulted in data coding according to a range of different themes, but the discussion of this article is based on, as mentioned, coding that was performed to specifically examine the three family constraints on reporting that were posed by Taylor and Putt (2007). This method of analysis aimed to ascertain whether non-CALD survivors of childhood sexual assault experience similar barriers to reporting that have been identified for other survivor populations, and to describe the nature of these barriers. Our approach was qualitative in its aim to understand the nature of the family constraints, rather than their prevalence, severity, or relative frequency compared to those of CALD victims.

\section{Family denial and trivialisation of disclosures}

Please try to make children who are sexually abused in the home feel ok to go to police...because it's hard when it's your father or other family members. Maybe have ads on television to show children and scare the offenders (Survey Respondent 47).

The above comment from a survey respondent was one of several similar comments from survivors alerting researchers to the problematic area of disclosing and reporting intrafamilial sexual abuse. Survey analysis from our study revealed that $66.0 \%$ of respondents reported a "fear of not being believed" by family members with the result substantially higher for females (69\%) than males (39\%).

In line with findings by Taylor and Putt (2007) and Taylor (2004), a number of survivors in our study encountered disbelief and outright rejection of their disclosure by mothers and other family members. What is poignant is that some survivors sought to disclose and re-disclose, even seeking one to one dialogue with individual family members in the hope that they may change their stance:

The second time I told my parents and nothing was done, the third time I told my parents and was disbelieved, the fourth time my mother initially believed me, then she didn't believe me, the perpetrator was exonerated (Survey Respondent 221).

[M]y father absolutely did not believe that his own father... could have sexually abused three girls, his own three granddaughters. It caused such devastation really for dad. He was absolutely horrified. I never actually spoke with dad directly, mum said to me that dad had said his father would never have done that, it's just not true, and he actually said that us three girls were lying, we must be lying because his dad would not do that (Individual Interview, Transcript 2).

My grandfather was a respected member... of the community.... he was idolised by [the] family with full knowledge of the sexual abuse of my mother (Survey Respondent 12).

In this next example the survivor sought dialogue with her siblings and in-laws in an attempt to have them understand and support her disclosure. She expressed feelings of distress at having to virtually mount a series of debates and arguments her siblings to counter the rejections of her disclosure and reporting to police:

First of all I reminded [siblings] that one of the main reasons I was taking this action [to report to police] was 
because of the [their own girl children]. I pointed out how it was likely they would feel great anger toward me if dad did abuse [their own daughters] and I later came and told them about my experience but hadn't bothered to warn them. That one garnered [sister-in-law's] sincere support [for a short time only] (Individual Interview, Transcript 31).

In a related vein some survivors experienced family members not explicitly rejecting the disclosure but partaking in a discourse of victim blame for the assault; trivialising the assault and ipso facto voiding the experience as a crime of sexual violence; or minimising or denying victim harm. One interviewee told researchers that "[m]y mum thought what he [the perpetrator] did was a mistake and [it was] not like he had murdered anyone, [and she is] in the process of moving back in with him, and I suspect will support him at the court case" (Individual Interview, Transcript 20). With regard to family members minimising harm or trivialising the abuse the following comments are instructive examples:

[when I told] family members they said I must have brought it on myself (Survey Respondent 300).

my father ridiculed me when I told him [of sexual abuse by relative] and I felt no one else would believe me either (Survey Respondent 103).

I told mum 3 years after the fact and she said it was all over with now [and to] get over it (Survey Respondent 215).

In another poignant example, another woman similarly told researchers she was unable to properly talk to family members about having sustained childhood sexual abuse because her husband and adult children believed she should have "gotten over it" now that she was aged in her fifties. This was in spite of the fact she suffered ongoing psychiatric illness as a result of severe and sustained assault by her father in childhood. Her 28-year-old son blamed her for "dragging down" the family finances because she was psychologically unable to manage paid work, and told her he didn't want her to have contact with his new born daughter because she was a "depressed grandmother". When she was later hospitalised for stomach surgery arising from years of depression, both her husband and eldest son refused to visit (Individual Interview, Transcript 23).

This tendency for families to believe that victims should "get over" sexual assault was particularly evident in cases where survivors had disclosed to family members after a delayed time period. Families can misunderstand delayed disclosure as somehow indicating successful "recovery", and a cultivated ability to cope with the crime sufficiently enough to open up about it. Families may not understand that a victim's recovery may be wholly unrelated to their motivation for disclosing sexual assault. On the contrary, survivors may disclose to family members precisely at a time when they find themselves no longer able to cope with the memory and feelings of victimisation. One interviewee expressed the view that disclosing was something she did because "she could no longer face living anyway” (Focus Group Interview,
Transcript 35), and another woman spoke of having approached police in a disassembled psychological state after reaching the point where she felt no longer able to deal with life (Focus Group Interview, Transcript 35). In the case of these two women, disclosure/reporting was driven by personal crisis, and was embarked upon as a last-ditch attempt to get relief from the emotional and mental pain of living with the consequences of crime.

While family members may adopt a disbelieving stance in terms of being unable or unwilling to understand the effects of sexual assault as being serious and far-reaching, respondents also spoke about family members expressing disbelief on the grounds that they were unable to see how they could have been unaware of abuse that was occurring within their own household. One woman recalled of her and her sisters' disclosure of intrafamilial sexual assault to their parents that, "unfortunately[,]...there was a lot of disbelief from our parents". She speculated this disbelief arose from the fact her parents were probably shocked and really unable to deal with the enormity of what was being told to them, and really hard to comprehend that this had been going on for a number of years in their home and they either didn't see it or weren't able to recognise the signs (Individual Interview, Transcript 2).

While family members might well be surprised at not knowing about the sex offending of fellow householders, this type of reaction is also largely derived from fears generated by the disclosure. Fear motivated by self-interest that the family will be torn apart by the disclosure; fears that the family name will be stigmatised; fear that the family will suffer irreparably financially and socially; fear of retribution by the offender against the victim and perhaps other family members and even general ignorance that such abuse simply could not have been perpetrated by the family member in question. It is often much easier to silence and expunge the victim from the family unit than face the shocking reality of sexual abuse within the family unit. These fears are most often internalised by victims who greatly fear disclosure to family members (Armstrong, 1994; Herman, 1981; Taylor, 2001, 2004). The aforementioned respondent described her relationship with her parents as having been "destroyed" by the fact they were unable to comprehend the fact she had been sexually assaulted by an extended family member in childhood (Individual Interview, Transcript 2).

The reactions of family members can deeply affect the confidence of a victim to disclosure further and report the crime, as indicated by this next respondent: I couldn't even get my family to believe me - [so] how on earth is a "jury of your peers" going to believe you (Survey Respondent 133). Police and other professionals need to be very aware of the extent to which family members can deny a victim's disclosure and it's flow on effect in terms of being able to report or disclosure the offence beyond the family walls.

\section{Denial and lack of support from mothers}

Researchers heard a number of accounts of mothers failing to appropriately support their daughters in exposing the sex crimes of male family members. One survivor reported that her mother's rejection of her disclosure of sexual abuse by her step-father destroyed their capacity for a relationship, however 
this young woman believed that the act of disclosure was liberating for her:

The relationship between myself and my mum has hit the point of no return, but I think it was always going to do that. I don't regret what has come out in the process (Survey Respondent 20).

In one particularly serious case, an interviewee said her mother viewed her husband's sexual abuse of his daughters as an "accident", and procured an abortion for her youngest daughter who had been impregnated by him. Further, this mother refused to believe that her eldest daughter's disabled daughter had been fathered by her husband. The following is an excerpt from the interview (Individual Interview, Transcript 3):

Respondent: He [my father] came out of jail and raped me at my friend's house. I fell pregnant with his daughter.

Interviewer: Your mother thought this was an accident?

Respondent: Yes, it shattered me. When all this came up in 2004/2005, my mother denied it all and blew up. She said, "when the [paternity] results come in I will believe you". The results came in and I have not spoken to her since...in court she sat on his side.

While the actions of this woman's mother were reprehensible, and she was rightly angry about them when speaking with the researcher, in discussing her experience we are mindful of the "mother-blame" discourse that permeates many discussions of childhood sexual abuse, and we do not suggest that mothers are primarily responsible for the obstacles to reporting that are enacted in families against victims. S. Caroline Taylor's research included cases where mothers supported their children's allegations of intrafamilial rape and sexual assault as well as mothers who rejected their daughter's disclosures and actively supported her husband, who was the perpetrator. In these cases the overarching dominance of the perpetrator was tangible. A significant body of research has analysed in depth the elevation of mother-blame in non-feminist psychological, medical and legal discourse and the flawed and at times misogynist rationale motivating such a discourse. Moreover, the notion that a mother's ubiquitous presence in the family is a safeguard against abuse and that a mother would somehow know if sexual abuse of her child were occurring are erroneous and ignore the role of perpetrators to both abuse their children and wholly dominate other family members (Taylor, 2001, 2004). The role that perpetrators play in creating an environment that leads women to abandon support for their child or grandchild was an experience for some of the women in our study as highlighted in following examples from our study. One young woman expressed disappointment about her grandmother's defence of her perpetrator grandfather at the time he was abusing her as a child. The grandmother had told her she was the "evil" one in the situation. The location of the victim as evil haunted her and prevented her from further disclosure and reporting. However, the survivor also acknowledged that her grandmother was "virtually a slave" to the perpetrator, and that "[h]e was an abusive horrible type of character and she was in great fear" (Individual Interview, Transcript 2). A survey respondent wrote that she has struggled to overcome her feelings of distress despite telling her mother, nothing was done: my mother knew what was happening, my sister (It was her husband who assaulted me) she knew, neither did anything to stop what was going on. The offender was a powerful person [in our family] (Survey Respondent 170). Another respondent wrote that she told her mother only to receive no concern or care and no action, leading the victim to suffer in silence for decades, and feel unable to disclose any further or report the matter (Survey Respondent 127).

\section{Family members closing ranks, taking sides and expelling victims to a familial wasteland}

This tendency for family members to deny, close ranks and to ostracise or to eject outright the survivor from the family unit has been discussed in some detail in the work of S. Caroline Taylor (2004) who linked these actions as resulting in various forms of social death for victims. The degree to which families can exact punitive retribution to a victim for disclosing sexual abuse by the father or other family member has also been articulated by the judiciary when sentencing perpetrators (see Taylor, 2001, 2004). This form of punishment metered out to survivors and its impact is discernible in the following examples relating to family rejection post disclosure:

[I feel] shame, because I feel I am a broken person and I feel I should cope better. I don't apply this standard to others, just myself. I felt so much horror that I needed time to process the rapes as a kid and a teenager... because few people in my family treated [offenders] like criminals. I was ostracized from family gathering and [offenders] were not... it takes a long time to get the true non-mythical story from the self-serving delusions from your family and your community (Survey Respondent 302).

My whole family rejected me...every living relative[,] all my friends and family. None of them would have a bar of me from the moment I walked out the front door. It's like I'd done this thing, and [my family says] no we're not going to [stand for] this, you can't break that secrecy. You can't break that code of silence (Individual Interview, Transcript 5).

[as a consequence of] telling I now have no aunts, uncles or cousins who will [speak to me]...I eventually reconciled with my brother and mother...but cannot forgive them for supporting my uncle at the time I [disclosed] (Survey Respondent 301).

Another survivor in a similar circumstance had nonetheless come to the view that she

would still have taken the steps that I did because although I have now lost any place in my extended family my integrity would not allow me to sell out the innocence and safety of my nieces in order to enjoy a position in a family (Individual Interview, Transcript 31).

Sometimes family members used the threat of rejection or the threat of emotional withdrawal or support as a means of 
dissuading survivors from further disclosure or reporting to police. These actions add another layer of trauma-laden decision making for victims who are faced with a most personal level of retribution should they disclose further. One woman who told her brother and sister that she wanted to report the sexual abuse of their father because she was reaching the point where she was unable to mentally cope with it anymore was told they would cut her out of their lives if she stepped forward, despite her sister having also been victimised (Individual Interview, Transcript 35). One young woman experienced dreadful obstacles being put in her way by her mother and grandparents for continuing with her decision to report her father's sexual abuse of her to police. They actively withdrew support for her to visit her youngest sister who suffered with a severe and debilitating disability. This blocking of access was clearly linked to the survivor's determination to maintain her police report and resulted in her having to initiate legal proceedings to secure a legal right to visit her young sister. These actions added to the distressing legal processes the survivor was going through as a consequence of her police report for sexual abuse at the hands of her father. Within that same year the survivor's youngest sister died as a consequence of her illness. In order to attend her sister's funeral the survivor had to seek further legal assistance to enable her to attend the event in safety and without harassment (Individual Interview, Transcript 24).

The young woman had to go to these lengths to continue contact with her sisters because her mother, aided by her grandparents and (perpetrator) father disallowed her any contact with family members from the time she reported to police. She was able to attend the funeral of her younger sister only as a result of intervention by the courts and police. At the time of interview, she had been granted permission to speak on the phone to her sole surviving sister on a weekly basis, but had not yet been allowed to see her in person.

There were other respondents who described efforts by family members to dissuade them from reporting by fostering disbelief among others about their disclosures. In several cases, families actively appealed to health workers that the victim was mentally ill. Respondents told researchers they believed these appeals were made specifically in order to protect male family members from the scrutiny of authorities. The woman cited earlier who was impeded in reporting the sexual abuse of her uncle witnessed her mother attempt to persuade hospital and community services staff that she was mentally ill (Individual Interview, Transcript 33). While this survivor had, indeed, suffered a mental illness earlier in her life, her mother used this medical history to convince hospital staff that her daughter's disclosures were incredible. In the case of another woman whose father physically and sexually abused her in a regional Victorian town throughout childhood, both of her parents attempted to convince counsellors (appointed by the court) that their daughter was mentally ill. She noted in an interview that, "even in our family counselling[,] they...my parents together decided that I had some mental illness and that's why I had lied about everything and made it up" (Individual Interview, Transcript 24).

Family environments in which women and girls are discredited as liars, unreliable or attention seeking might be understood as constituting a specific "familial cultural" barrier to the reporting of sexual assault. While research on women from CALD backgrounds indicates that family members "never believing" sexual assault victims is a substantial barrier for victims (Taylor \& Putt, 2007), the women in our sample experienced a range of denials across a spectrum that included explicit denials, trivialising and minimising harm and casting the victim as unstable and thus unreliable.

\section{The Nexus of 'fear', 'shame' and burdening family through disclosure or reporting}

Analysis of the survey and in-depth interview data revealed the large scale impact of negative emotions such as feelings of shame, stigma, stigma threat, and guilt experienced by victim/ survivors, which impeded their capacity to both report sexual victimisation to police and to disclose to others. Feelings of shame and fear of being stigmatised resulted in significant isolation in terms of fear-induced silence and non-reporting (see also Weiss, 2010, who identified similar findings). Survey results showed that $72.5 \%$ of survey respondents reported feelings of "stigma" and $76.6 \%$ "feelings of shame". More specifically, $78.4 \%$ of respondents reported a "fear of bringing shame to the family". As such feeling of, and a fear of attracting shame was a visceral feeling and one which survivors also felt may also be attached more generally to their family:

I didn't want to cause my family to feel shame like I did because I knew it would just destroy them... it's bad enough that I feel stigmatized without sharing the burden on them... (Individual Interview, Transcript 39).

[I felt] too ashamed to talk about it to anyone... Things may be getting different now but the shame of incest has been too much for me to bear. It has destroyed much of my life. I don't believe I have been the best wife or mother I could have been. I cannot talk about it to anyone because of the shame I feel (Survey Respondent 21).

I didn't want to cause my family to feel shame like I did because I knew it would just destroy them... it's bad enough that I feel stigmatized without sharing the burden on them.... (Individual Interview, Transcript 39).

And 'cos of that [feelings of shame] I didn't want to (report) 'cos it would bring shame on our name (Focus Group Interview, Transcript 42).

The predominance of these findings in the survey make clear that feelings of shame and stigma are not culturally specific. Of concern was the finding that those reporting feelings of shame and stigma were unlikely to seek support from friends, family and professionals and were less likely to report to police.

Linked closely to these negative feelings and fears was the fear that disclosure would be a burden to family members. The degree to which women believed disclosures of childhood sexual abuse would unfairly burden family members emerged as a theme particularly for women who reported inadequate feelings of self-worth. One interviewee expressed the opinion that her own perceived lack of self worth had led 
her to decide against telling her children about her history of sexual assault in childhood:

...you become like a martyr. You don't want to burden anyone. That's because of your own self-worth, you don't feel like you are anyone. And so you keep it tucked away....because you feel like you are nothing (Individual Interview Transcript 44).

This woman felt she was not entitled-even as a 45-year-old full-time professional with teenage children-to burden her family with the pain she carried as a result of years of sexual abuse. She remarked that she hadn't disclosed the information to her teenage children who were sitting high school exams because she didn't think it would be fair to burden them at this important time in their lives. This expectation that women and girls are responsible for protecting the emotional and physical wellbeing of family members can cause them to hide or minimise their experiences of sexual assault, and this doesn't auger well for their ability to report the crime. One survivor expressed the view that her disabled younger brother was already a handful for her parents, and so her experience of violent rape outside the family as a 15 -year-old was not something she felt able to burden her parents with at the time. Even looking back as an adult, she doubted whether her parents would have taken the assault seriously anyway, given other problems they faced at the time with having ten children (Focus Group Interview, Transcript 23). In another woman's case, her mother had just given birth to a male sibling, and had a sad history of suicide attempts. As a sixteen-year-old, this woman thought that telling her mother about having been raped might have put her mother at risk of self harm (transcript 9). Another respondent wrote in the online survey that, "[w]hile I still ha[d] family members alive, I didn't want them to feel that they should have known and feel guilty for not knowing" (Survey Respondent 94). Similarly, while another woman regretted the fact that family barriers had prevented her obtaining "justice", her concern for her mother's wellbeing outweighed her belief that the perpetrator should not "get away with it so easily":

I sometimes wish that I had [reported], for [the sake of] justice - so that he didn't get away with it so easily. But overall, I still probably wouldn't have simply to protect my family from small town gossip and to save my mother from experiencing the probable pain and guilt that a parent would feel (Survey Respondent 140).

\section{Reluctance to report perpetrators based on fear}

Survivors of intrafamilial sexual abuse have nothing to gain and everything to lose from disclosing the crime (which is most cases) and survivors receiving inadequate, poor and even violent reactions from family members to disclosure is sadly an all too common feature of intrafamilial sexual abuse (see Taylor, 2001, 2004). In our study, actual familial responses, or a fear of how family might respond to disclosures were significant factors that inhibited the ability of survivors to report the abuse to police. Statistical analysis of our online survey revealed the degree to which victims of sexual violence were either fearful of disclosing to family members or were intimidated either by the offender or other family members against disclosure and/or making a report to police. It is illustrative that when the offender was reported as being related to the victim, $88.2 \%$ of respondents reported a "fear of family" with regard to reporting/disclosing. Other findings included:

- $42.9 \%$ reported a "fear of losing family support" if they reported.

- $35.4 \%$ reported a "fear of family breakdown" if they reported.

- $72.5 \%$ reported "intimidation" by the offender as a reason they feared reporting the offence.

- $66.1 \%$ reported "concerns" for their safety if they disclosed.

- 33.1 reported "concern" for the safety of others if they disclosed.

- $43.3 \%$ reported "experiencing fear" of others finding out they had been sexually victimised.

Threats to harm or kill victims or other family members or pet featured heavily in our data and the following examples are reflective of the general tenor of comments pertaining to this:

He threatened to kill me if I told anyone (Survey Respondent 33).

I didn't want to break up the family and I was told nobody, including police would believe me, and [offender] threatened to kill me (Survey Respondent 66).

I'd been told by my father that he'd kill my mother and that he'd kill me if I told anyone and he was very physically abusive so I had this fear in the back of my mind that I couldn't [report] (Focus Group Interview, Transcript 35).

Firstly he told me he would kill me but first he would kill my mother in front of me (Individual Interview, Transcript 44).

Extra-familial offenders are likely to use threats and intimidation against victims also, but the added layer of terror and fear for intrafamilial victims is the lineal relationship and proximity of the offender, giving them access and surveillance of the victim $24 / 7$, and thus the capacity to exert and reinforce their threats and dominance (see Taylor, 2001, 2004).

In one particularly sad account recorded by researchers, a survivor recalled the means by which her perpetrator father manipulated her in order to continue his assaults:

Because I knew if I didn't stop him if he wasn't happy with me, he would go hunting elsewhere and I didn't want that. And then sometimes I would buck the system a bit and say no, then he would become very vicious, tongue lashings with my mum and my sister and myself and then the wheels would fall off in the house and my mum would say, "what is wrong with him, god you know I wish to god he would get it out of his system". You know then she would get upset and then I would think it's not worth it, I'm only making things worse for everybody. Give in and go back to it....and he threatened...he said he'd kill my dog...sometimes I'd race home from school and the first 
thing I'd do is a headcount to make sure all [pets] were accounted for... (Individual Interview, Transcript 19).

This form of threat made by perpetrators against victims serves a common end in coercing victims into continued acquiescence, and continued silence, about the crimes being perpetrated against them. This form of intimidation is particularly relevant to our discussion of family-based barriers to reporting, given that this technique involves perpetrators exploiting a victim's role within the family unit - an issue discussed at some length in the work of S. Caroline Taylor (2001, 2004). Without the commitment of victims to their mothers and siblings and the general wellbeing of the household, perpetrators would not be as successful in waging this type of threat. It is therefore a particularly illustrative example of how perpetrators are able to mobilise the family unit in defence of their crimes.

The rational basis upon which victims are frightened and even terrified to report sexual assault in the face of death threats to themselves and their family members is a barrier that is difficult for victims to overcome and represents a challenge for police in terms of having victims trust them enough to report the crime. The same rational basis for failing to approach police can be found, of course, in a range of crimes where witness protection measures are deemed necessary. Crimes involving intra-familial sexual assault should be considered "high risk" in terms of the likelihood of victim intimidation and extortion, given the depth of knowledge that perpetrators have of their victims, and the ability they therefore have to enforce silencing tactics against them (see Taylor, 2004). The police and the public might become better informed about the prevalence and severity of threats made by sexual assault perpetrators against their victims in relation to cooperating with police. The impact of perpetrator threats on the ability of victims to approach police is an area of future research that might yield significant insights for policing practice.

\section{Discussion}

Families exist within a social environment that is generally unsympathetic to rape victims, particularly female ones (Costin \& Schwarz, 1987, pp. 894-901; Flood \& Pease, 2006). Families are also beset by a lack of knowledge of the crime, particularly in regards to intrafamilial child sexual abuse. Researchers in Australia in 2009 found that "critical information about CSA [child sexual assault] cases is outside of the experience and common knowledge of laypeople" (Cossins, GoodmanDelahunty, \& O'Brien, 2009, p. 445). They noted that stereotyped and unsympathetic ideas about child sexual assault still circulate popularly among the Australian population. Unsympathetic responses to survivors can stem from the circulating idea that sexual assault does not inflict particularly serious or ongoing harm on victims (Feldman-Summers \& Palmer, 1980, p. 19-40; Madigan \& Gamble, 1989), and that victims who are unable to "successfully" move on with their lives after assault are overreacting or being self-absorbed (Taylor \& Mouzos, 2006). Insensitivity may also result from general public unawareness of the lifelong health problems that victims of childhood sexual assault endure (Nelson, 2000; Taylor \& Pugh, 2010; Taylor, Pugh, Goodwach, \& Coles, 2012).
The tendency for families to blame the victim for bringing the crime upon themselves is reflective of the wider social view that women are responsible for men's abusive behaviour (Ben-David \& Schneider, 2005; Davis, Taylor, \& Bench, 1995; Pollard, 1992). While we might not expect families to be in a position to buck this entrenched social belief, their prejudicial views have an especially direct and serious impact on sexual assault reporting (Thapar-Björkert \& Morgan, 2010, pp. 32-59). The 1996 Women's safety survey found that victims of sexual assault consult friends and family before they consult police, work colleagues, counsellors, legal practitioners, and doctors about the crime (Australian Bureau of Statistics, 1996; Stein \& Nofziger, 2008, pp. 158-177). This means that a major crutch to reporting is removed for survivors who encounter disbelief from family members upon disclosure. Feminists have discussed the problem of women being unable to comprehend their own sexual victimisation as a "real" crime deserving of official remedy (Easteal \& McOrmond-Plummer, 2006). Trivialisation of sexual assault by family members compounds this already existing tendency for women not to report on the basis that they are unable to perceive of themselves as socially worthwhile enough to be deserving of protection by public agencies like the police (Miller, Handley, Markman, \& Miller, 2010, pp. 1120-1137).

The problem of family members seeking to encourage disbelief among others and discredit victims was addressed by Sarah Nelson (2000) who argued for professional and social service organisations to stand up publicly in support of survivors and against the "misrepresentation" and "distortion of facts" that is carried out against victims who speak up (p. 387). The social environment that surrounds child sexual abuse can be not only unsupportive of survivors, but also their supporters. In critiquing those who say that mothers "collude" with their offending male partners in orchestrating the sexual abuse of children, Armstrong (1983) notes widespread evidence from the courts of mothers attempting to protect children from perpetrators by removing them from the household after disclosures of sexual abuse. She notes that the courts and child custody systems are often unsupportive of mothers who take these steps to protect children from the sex offending of their fathers. While this evidence does not ameliorate the emotional pain survivors feel when their mothers fail to support them, it does highlight the extent of social forces that work against the building of a community environment that is encouraging of sexual assault crime victims and their supporters approaching police.

In the case of women from CALD backgrounds, the "social forces" that work against their successful reporting of sexual assault crime may be described as "cultural" in so far as notions of family shame appear to be a more prominent dissuading factor. However as our study shows, shame was an influence that also dissuaded women from non-CALD backgrounds reporting to police. It was also an element linked to a belief that shame would be transferred to the family unit as well thereby creating a further consideration against reporting as victims took account of exposing their family to shame and stigma. This sense of not wanting to burden or cause distress to families is indicative of the sense of responsibility victims' adopted and in doing so, put subjugated and suppressed their own welfare and feelings in order to protect the family unit. 
In addition many victims feared rejection by family members as a result of causing them "trouble" through reporting sexual assault. Similar to CALD and Indigenous women, non-CALD women were inhibited in reporting by the thought that they would be ostracised by family members. Indeed, many women who did report found themselves facing hostility from whole families. This familial reaction from non-CALD Australian families that disbelieves victims, sides with perpetrators and expunges victims from the family unit with accusations they are liars or mentally ill and bringing shame upon the family has been documented by Taylor (2001, 2004). We contend that this "familial culture", as distinguished from some aspects of ethnic cultures that potentially impede reporting (e.g., honour), is a factor commonly encountered by a broad range of victims of sexual assault, regardless of their cultural backgrounds.

\section{Conclusion}

While some question the value of police taking on a "mediation" role in relation to crimes against women (Breci \& Murphy, 1992), police have nonetheless already begun to play a more proactive role in dealing with family violence and advocating for the rights of women as targeted victims of domestic and sexual violence (Council of Europe, 2008). There is, in our view, a role for police in ensuring the safety and well-being of a victim who discloses abuse by a family member (or even non-family member) where the victim feels they are in danger of retribution, disbelief, losing family support, or being expelled from the family unit. This is where a police sexual violence liaison officer could play a role in promoting confidence and trust among victims to report and to feel supported post-disclosure/reporting. Police and social services may also need to champion the cause of victims against institutions that have been co-opted by hostile family and community interests, particular in the case of victims who find themselves contending with families that have institutional backing. The close coordination of police with social services is a particular need in the case of victims reporting intrafamilial sexual assault, given the risk of homelessness they face. Even when victims are able to resist the attacks of perpetrators and find the wherewithal to escape the household, they can come under the threat of homelessness (and therefore further victimisation) as a result. Survivors who disclose or report sexual abuse by family members are also at risk of homelessness through being expunged from the family by household members who aim to threaten the victim into silence. We see an opportunity for further research in this area to address the range of tactics that perpetrators and their supporters use against victims in defending themselves against exposure for sexual assault crime. Police and other social service agencies are vulnerable to manipulation by perpetrators against family complainants, and this has serious consequences for the ability of victims to continue with reporting. We believe that further research in this area will better prepare police to combat the "family barriers" that victims face, and which contribute to low rates of reporting of intrafamilial sexual assault in particular.

\section{Endnotes}

${ }^{1}$ For the purposes of this research we ignore the 'partner' qualifier.
2 See, for example, Koch and Jarvis (1987) and Thompson-Cooper (2001). For critiques of these discourses, see Caplan and Hall-McCorquodale (1985), Elbow and Mayfield (1991), Jacobs (1990), and Schonberg (1992).

\section{References}

Aly, Anne, \& Gaba, Gadija (2007). No place to go: Report on the needs analysis of crisis accommodation for culturally and linguistically (CaLD) background people (Islamic). Canberra: Department of Families, Community Services and Indigenous Affairs.

Armstrong, Louise (1983). The home front: Notes from the family war zone. New York: McGraw-Hill.

Armstrong, Louise (1994). Rocking the cradle of sexual politics. California: Addison-Wesley.

Australian Bureau of Statistics (1996). Women's safety Australia 1996. Cat. No. 4128.0. Canberra: Australian Bureau of Statistics (Retrieved from http:// www.ausstats.abs.gov.au/Ausstats/subscriber.nsf/0/F16680629C465E03CA2 56980007C4A81/\$File/41280 1996.pdf)

Australian Institute of Family Studies (2007). Secondary victims' of sexual assault. ACSSA Issues No. 7, June 2007 (Retrieved from http://www.aifs. gov.au/acssa/pubs/issue/i7pdf/acssa_i7_secondary.pdf)

Ben-David, Sarah, \& Schneider, Ofra (2005). Rape perceptions, gender role attitudes, and victim-perpetrator acquaintance. Sex Roles, 53(5/6), 385-399, http://dx.doi.org/10.1007/s11199-005-6761-4.

Breci, Michael, \& Murphy, John (1992). What do citizens want police to do at domestics: Enforce the law or provide services. American Journal of Police, XI(3), 53-68.

Caplan, Paula J., \& Hall-McCorquodale, Ian (1985). Mother-blaming in major clinical journals. The American Journal of Orthopsychiatry, 55(3), 345-353.

Cossins, Anne, Goodman-Delahunty, Jane, \& O'Brien, Kate (2009). Uncertainty and misconceptions about child sexual abuse: Implications for the criminal justice system. Psychiatry, Psychology and Law, 16(3), 1-18.

Costin, Frank, \& Schwarz, Norbert (1987). Beliefs about rape and women's social roles: A four-nation study. Journal of Interpersonal Violence, 2(1), 46-56.

Council of Europe (2008). Combating violence against women: Minimum standards for support services. Retrieved from. http://www.coe.int/t/ dg2/equality/domesticviolencecampaign/Source/EG-VAW-CONF(2007) Study\%20rev.en.pdf

Davis, Rob, \& Brickman, Ellen (1996). Supportive and unsupportive aspects of the behavior of others toward victims of sexual and nonsexual assault. Journal of Interpersonal Violence, 11(2), 250-262.

Davis, Rob, Taylor, Bruce, \& Bench, Sarah (1995). Impact of sexual and nonsexual assault on secondary victims. Violence and Victims, 10(1), 73-84.

Department of Families, Community Services and Indigenous Affairs (2007). Report on the needs analysis of crisis accommodation for culturally and linguistically (CaLD) background people (Islamic). Retrieved from. http:// www.fahcsia.gov.au/sa/housing/pubs/women/dar_al_shifah/Documents/ Needs_Analysis.pdf

Easteal, Patricia, \& McOrmond-Plummer, Louise (2006). Real rape, real pain: Help for women sexually assaulted by male partners. Ormond, Vic.: Hybrid Publishers.

Elbow, Margaret, \& Mayfield, Judy (1991). Mothers of incest victims: Villains, victims, or protectors? Families in Society: The Journal of Contemporary Human Services, 9(2), 78-86.

Fairfield Multicultural Family Planning (1996). Many voices, different stories: A conference on speaking out about cultural diversity and sexual assault: 8th E' 9th May 1996. Australia: National Women's Health Program.

Feldman-Summers, Shirley, \& Palmer, Gale (1980). Rape as viewed by judges, prosecutors, and police officers. Criminal Justice and Behavior, 7, 19-40.

Flood, Michael, \& Pease, Bob (2006). The factors influencing community attitudes to violence against women: A critical review of the literature. Melbourne: Victorian Government.

Goudriaan, Heike, Lynch, James, \& Nieuwbeerta, Paul (2004). Reporting to the police in western nations: A theoretical analysis of the effects of social context. Justice Quarterly, 21(4), 933-969.

Heenan, Melanie, \& Murray, Suellen (2006). Study of reported rapes in Victoria 2000-2003: Summary research report. Melbourne: State of Victoria.

Herman, Judith (1981). Father-daughter incest. Massachusetts: Harvard University Press.

Home Office Research, Development and Statistics Directorate (2005). A gap or a chasm?: Attrition in reported rape cases. London: Home Office Research, Development and Statistics Directorate (Retrieved from http://rds.homeoffice. gov.uk/rds/pdfs05/hors293.pdf)

Itzin, Catherine (2001). Incest, paedophilia, pornography and prostitution. Child Abuse Review, 10(1), 35-48.

Jacobs, Janet L. (1990). Reassessing mother blame in incest. Journal of Women in Culture and Society, 15(3), 500-514.

Jordan, Jan (2004). Beyond belief?: Police, rape and women's credibility. Criminal Justice, 4(1), 29-59. 
Koch, Kathleen, \& Jarvis, Carolynne (1987). Symbiotic mother-daughter relationships in incest families. Social Casework, 68(2), 94-101.

Lievore, Denise (2003). Non-reporting and hidden recording of sexual assault: An international literature review. Department of the Prime Minister and Cabinet (Retrieved from http://www.aic.gov.au/documents/D/4/6/\%7BD4631AC02DDC-4729-AD3C-8A69DF33BA65\%7D2003-06-review.pdf)

Lievore, Denise (2005). No longer silent: A study of women's help seeking decisions and service responses to sexual assault. Canberra: Australian Institute of Criminology.

London Metropolitan Police (2008). Don't be afraid to report rape and sexual assault, 'Campaign results'. Retrieved from http://content.met.police.uk/ Article/Dont-be-afraid-to-report-rape-and-sexual-assault-Campaign-results/ 1400002039898/sapphirecampaign08

Madigan, Lee, \& Gamble, Nancy (1989). The second rape: Society's continued betrayal of the victim. New York: Lexington Books.

Miller, Audrey, Handley, Ian, Markman, Keith, \& Miller, Janel (2010). Deconstructing self-blame following sexual assault: The critical roles of cognitive content and process. Violence Against Women, 16(10), 1120-1137.

Minichiello, Vince, Sullivan, Gerard, Greenwood, Ken, \& Axford, Rita (Eds.). (2003). Handbook of research methods in nursing and health science (2nd ed.). French's Forest, NSW: Pearson/Prentice Hall.

Neame, Andrea, \& Heenan, Melanie (2004). Australian Institute of Family Studies briefing. Responding to sexual assault in rural communities. Australian Institute of Family Studies.

Nelson, Sara (2000). Confronting sexual abuse: Challenges for the future. In Catherine Itzin (Ed.), Home truths about child sexual abuse: A reader (pp. 387-402). London and New York: Routledge.

Perlesz, Amaryll, \& Lindsay, Joe (2003). Methodological triangulation in researching families: Making sense of dissonant data. International Journal of Social Science Research Methodology: Theory and Practice, 6(1), 25-40.

Pollard, Paul (1992). Judgments about victims and attackers in depicted rapes: A review. British Journal of Social Psychology, 31, 307-326.

Rafanello, Donna (2004). Can't touch my soul. California: Alyson Publications.

Rubin, Pamela (2010). When women speak to power about restorative justice. In James Ptacek (Ed.), Restorative justice and violence against women (pp. 79-102). Oxford; New York: Oxford University Press.

Ruddick, Sara (1997). The idea of fatherhood. In Hilde Lindemann Nelson (Ed.), Feminism and families (pp. 205-220). New York and London: Routledge.

Russell, Diana (1986). The secret trauma: Incest in the lives of girls and women. New York: Basic Books.
Schonberg, Ila J. (1992). The distortion of the role of mother in child sexual abuse. Journal of Child Sexual Abuse, 1(3), 47-61.

Stein, Rachel, \& Nofziger, Stacey (2008). Adolescent sexual victimization choice of confidant and the failure of authorities. Youth Violence and Juvenile Justice, 6(2), 158-177.

Taylor, S. Caroline (2001). The legal construction of victim/survivors in parent/child intrafamilial sexual abuse trials in the Victorian county court of Australia in 1995. PhD Thesis. School of Behaviour and Social Sciences. University of Ballarat.

Taylor, S. Caroline (2003-2004). Public secrets, private pain: Difficulties encountered by victim/survivors of sexual assault in rural communities. Australian Journal of Women Against Violence, 15, 12-21.

Taylor, S. Caroline (2004). Court licensed abuse. New York: Peter Lang.

Taylor, Natalie, \& Mouzos, Jenny (2006). Community attitudes to violence against women survey 2006: A full technical report. Canberra: Australian Institute of Criminology.

Taylor, S. Caroline, \& Pugh, Judith (2010). Happy, healthy women. Edith Cowan University.

Taylor, S. Caroline, Pugh, Judith, Goodwach, Raie, \& Coles, Jan (2012). Sexual trauma in women - The importance of identifying a history of sexual violence. Australian Family Physician, 41(7), 538-541.

Taylor, Natalie, \& Putt, Judith (2007). Adult sexual violence in Indigenous and culturally and linguistically diverse communities in Australia. Canberra: Australian Institute of Criminology.

Thapar-Björkert, Suruchi, \& Morgan, Karen (2010). But sometimes I think ... they put themselves in the situation: Exploring blame and responsibility in interpersonal violence. Violence Against Women, 16(1), 32-59.

Thompson-Cooper, Ingrid K. (2001). Child welfare professionals and incest families: A difficult encounter. Aldershot: Ashgate.

Ullman, Sarah, \& Najdowski, Cynthia (2011). Prospective changes in attributions of self-blame and social reactions to women's disclosures of adult sexual assault. Journal of Interpersonal Violence, 26(10), 1934-1962.

Victoria Police (2009). Living free from violence: Upholding the right. Retrieved from http://www.police.vic.gov.au/retrievemedia.asp?Media_ID $=49202$

Weiss, Karen (2010). Too ashamed to report: Deconstructing the shame of sexual victimization. Feminist Criminology, 5(3), 286-310.

Women's Legal Services NSW (). A long way to equal: An update of 'Quarter way to equal: A report on barriers to access to legal services for migrant women'. (Lidcombe, NSW). 